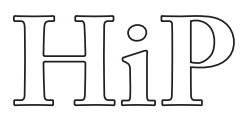

Historia i Polityka

No. $14(21) / 2015$, pp. 91-100

ISSN $1899-5160$

www.hip.umk.pl

DOI: http://dx.doi.org/10.12775/HiP.2015.023

Marina A. NAIDYCH

Lesya Ukrainka Eastern European National University, Lutsk, Ukraina

\title{
Volunteering as a Vector of EU Youth Policy
}

\begin{abstract}
The article deals with the legal framework of the European Union, aimed at regulation and promotion of volunteering. We investigate the availability of legislative documents in the community of each country and analyze the factors that influence the willingness or reluctance of young people to get involved in volunteer projects. The basic problems on the way of popularizing volunteer activity and the core issues of youth volunteering in Ukraine are determined.
\end{abstract}

Keywords: European Union, Ukraine, youth policy, regulatory framework, volunteering, monitoring tools, methods of promotion

Volunteering is, primarily, the ability to realize yourself, to help those people who do not have this opportunity to acquire new knowledge and skills while you share your own. Volunteer activities existed since ancient times. Representatives of the Samaritans can be called the first. Modern society is actively implementing the principles of volunteering. Youth participation in volunteering not only promotes social and economic solidarity in society in general, but also benefits the volunteers themselves. First of all, it strengthens youth engagement, increasing understanding of the necessity of participation in public life. That is why the European institutions draw attention to the necessity of development and support voluntarism.

\section{Legislative Base of EU}

The first official document, which dealt with the necessity of the development and promotion of volunteerism were recommendations on the development of the field 
of volunteering ${ }^{1}$, published in 1994. An important document for the development of long-term transnational voluntary work was the "Convention on the promotion of transnational long-term voluntary service for young people" 2 . The document was opened for signature in 2000, but as of 2010 only five EU countries signed it and only Luxembourg ratified it ${ }^{3}$. In 2002 a resolution ${ }^{4}$ which enhances the value of volunteering for young people was adopted.

White Paper A New Impetus for European Youth 5 identifies Volunteer activities as a priority direction for future cooperation in the youth field. That is why the research of EU volunteering is so important. The analysis will be based on the EU-prepared newsletters about volunteering in individual countries, as well as the general report of the European Parliament on youth policy. The practice of development, support, and promotion of volunteering varies in the EU countries. According to the newsletters provided by Member States, in most countries there is a policy to volunteering at the national, and sometimes at the regional level. However, this fact did not contribute to the development of specialized legislation in all countries that maintain the availability of specialized policies.

\section{Specialized Policy and Laws of the EU}

Among the European countries that have produced newsletters, nine developed appropriate regulations. In particular, there is a law about volunteering in Croatia $^{6}$; the law for the promotion of youth volunteers' services in Germany; the law about voluntary organizations in $\mathrm{Malta}^{7}$; and the basic document about gener-

\footnotetext{
${ }^{1}$ Recommendation no. R (94) 4 of the Committee of Ministers to Member States on the Promotion of a Voluntary Service (Adopted by the Committee of Ministers on 24 May 1994 at the 513th Meeting of the Ministers' Deputies) 1994.

2 Convention on the Promotion of a Transnational Long-term Voluntary Service for Young People, Strasbourg 11.05.2000.

${ }^{3}$ European Convention on the Promotion of a Transnational Long-Term Voluntary Service for Young People, CETS no. 175, 200.

${ }^{4}$ Resolution of the Council and the Representatives of the Governments of the Member States, Council meeting of 14 February 2002 on the added value of voluntary activity for young people in the context of the development of Community action on youth (2002/C 50/02), Official Journal of the European Communities, 23.02.2002.

5 European Commission (2001), A New Impetus for European Youth, White Paper. COM(2001) 681 final. Brussels 2001.

${ }^{6}$ Zakon o volonterstvu, [Law on Volunteering], Klasa: 011-01/07-01/47, Urbroj: 1-05-03/1-072, Zagreb 2007.

7 Voluntary Organisations Act. To regulate voluntary organisations and their administration, $11^{\text {th }}$ December, 2007. ACT XXII of 2007, as amended by Legal Notices 427 of 2007 and 177 of 2012.
} 
al recommendation concerning volunteerism in Romania ${ }^{8}$. Lithuania has adopted a number of laws and strategies relating to volunteerism?. In particular, the law concerning activities of volunteers. In Poland a long-term policy for developing volunteerism has been developed ${ }^{10}$. The status of volunteers was outlined in the law on social benefits of volunteering. One of the main documents directly related to the industry is the Wemenders Foundation Volunteering Strategy ${ }^{11}$.

Eight states reported having a policy aimed at volunteer activity, but special regulations were still to be developed. In such countries, volunteering is coordinated in regional documents. For example, in Italy, the social value of volunteering is described in the Law № 266/1991 ${ }^{12}$. In this country, each region is a manager who is responsible for social policy and volunteerism. Bulgaria uses regulations developed at the EU level, in particular, in the EU Youth Strategy 2010-2018, European Youth Pact and the White Paper on Youth. Also, the country adopted a national youth strategy for 2010-2020, one of the main parts of which is "Youth volunteering". In Luxembourg, volunteer activities are regulated within the legal framework of youth policy. In the Netherlands, governments as well as non-governmental organizations support volunteer activities at the national, regional, and local levels.

There are some countries that are not consciously focused on developing a specialized policy and a legislative process in this area. For example, France and Sweden. We also cannot find specialized national policy on volunteering in Greece. In France we discover an interesting division of volunteers into bénévolat and service civique. The first type is characterized by absolute altruism (not paid at all, these volunteers have no legal status); the second is defined as civil service and provides specific, social guarantees.

The issue concerning the legal registration of volunteering is the legal status of volunteers. According to this criterion, the EU can also be divided into two categories. Some courtiers (Cyprus, Greece, Ireland, and Malta) do not provide any guarantees for volunteers. In other, volunteers are provided with financial and

8 Legea voluntariatului, [Volunteering Law], publicata in Monitorul Oficial 2001, no. 206.

9 Lietuvos Respublikos, Savanoriškos Veiklos Istatymas, [Lithuania, the Republic of Voluntary Activities Act], Nr. XI-1500, Vilnius 2011.

10 Strategia Wolontariatu Fundacji Wemenders [Wemenders Foundation Volunteering Strategy], http://wemenders.pl/images/pdf/Strategia_Wolontariatu_Fundacji_Wemenders.pdf (accessed 24.02.15).

11 Strategia Wolontariatu Fundacji Wemenders [Wemenders Foundation Volunteering Strategy], http://wemenders.pl/images/pdf/Strategia_Wolontariatu_Fundacji_Wemenders.pdf (accessed 24.02.15).

12 S. Rota, Information Sheet "Volunteering of Young People”, Italy. 
social benefits (Belgium, Luxembourg, Slovenia, and Romania). In Finland, tax volunteering depends on a number of interpretations. In practice, the legal status of volunteers is rather ambiguous.

\section{Payment}

One of the criteria of willingness or unwillingness to engage young people in volunteering are the payment services provided. Clearly, volunteer activities include selfless help, but not all are able to invest their own money, effort, and time into such projects. That is why in most European countries compensation of certain expenses incurred by the volunteer is expected. Many countries return funds for travel and meals provided for most coordinating organizations (Lithuania, Poland, France, and the Netherlands). In all EU countries offset funds are not taxed as money received by voluntary organizations in form of donations.

Volunteers receive pocket money in Luxembourg. Volunteers working in the field of health care, rescue and sports are provided with insurance against accidents. In other cases, organizations draw up a separate insurance.

In Austria, instead of returning the money spent, or in addition to it, vouchers are also issued. In Belgium (Flanders) money is refunded at a rate not exceeding the defined daily or annual limit. In Slovenia, the work is not paid, but insurance is provided under the pension and disability insurance. German volunteers receive for their activities lump sum payments and pocket money. Also, they are returned the money spent for the operation. Since 1 January 2007 government reduces taxation amounting to 500 euros per year for persons engaged in volunteer activities.

Within the program "Youth in Action" volunteer activities in all countries are paid and include: travel, accommodation, food, pocket money, and so on.

\section{Monitoring}

An important factor in the regulation of any activity is monitoring. However, not in all European countries this unification is carried out on the national level. In particular, in Cyprus, Sweden, the Netherlands, Greece, Ireland, Italy, Malta, and Slovenia a general monitoring system is not developed. In other countries (Poland, Bulgaria, and Finland), monitoring is carried out only under the "Youth in Action". 
In France, the newsletter states that monitoring information is given each year. In Croatia, research is carried out by the Working Group to eliminate borders and increase international mobility in education. In Germany, the national monitoring activities engaged in volunteer service organization. In particular, the organization "weltwärts" (volunteer service of the German Federal Ministry for Economic Cooperation and Development) collects the following data:

- The number of young people being involved in volunteering abroad;

- Countries where the volunteers were sent to;

- The number of guiding institutions;

- The number of tasks sorted by continent;

- The number of tasks sorted by the field of activity;

- Average age;

- Gender;

- The average length of stay abroad ${ }^{13}$.

In Luxembourg, there is no national monitoring, but statements of various organizations to participate in the Youth Volunteer Service are being prepared.

\section{Means and Methods of Promotion}

It is important to begin involvement in volunteer activities as soon as possible; in the future that will increase the number of volunteers in the adult population. For this purpose a thorough work is conducted in most EU countries. Methods and measures used for this are extremely diverse: from leaflets and posters in places with large concentrations of people, summer camps, to special awards, including international ones.

One of the most popular means of spreading information about the opportunities for volunteer service assignment are youth information centers. These exist in almost all countries of the European Union. With state and local media such as television and press, much of the youth network recently acquired online also receives the necessary data concerning voluntarism. In Estonia, newsletters with relevant information are sent in youth centers of labor. It is also popular to attend seminars and conferences, forums and photo exhibitions, as well as watch movies dedicated to volunteering. Also, information is being spread among peers during conversations. Very interesting and effective is the example of Estonia, which im-

\footnotetext{
${ }^{13}$ K. Wondratschek, Information Sheet "Volunteering of Young People”, Germany 2011.
} 
plemented the "workshop of ideas" ${ }^{14}$. The purpose of the meeting was to generate as many constructive suggestions regarding the most acute problems for the participants. In this way, new solutions to problems are offered and information about the opportunities involving citizens in such activities is spread.

For example, in Cyprus the educational system indirectly contributes to the promotion of volunteering. The Ministry of Education and Culture, in collaboration with the Volunteer Coordination Council organized the program "Youth and volunteering". As part of the program, all schools in Cyprus participate in the contest of volunteer projects. In addition, in early December in all schools the "Week of Volunteering" is organized and for 5 days each school takes various initiatives (such as planting trees, visiting children's hospitals, etc.). The Cyprus Youth Council coordinated the activities of youth information centers, which not only distribute information on voluntary activities (posters, leaflets, and web pages), but also allow the interested persons to directly get in touch with the organizers of each event. It also supports interactive informal education of children of school age. This is encouraging volunteering since childhood, with youth learning to volunteer as a natural process.

French authorities do not interfere in voluntary service, considering it a personal choice of each individual. However, volunteers of service civique (civil service) are certain to encourage and facilitate the work. In particular, for young people under 25 involved in the activities of associations related to formal education, youth or sports, the officials may provide additional work weekends. They also have the opportunity to acquire some skills during training, paid by the state.

The Ministry of Education and Culture of Finland funded the project "Online Democracy". Every year, on 5 December, in this country there is the International Volunteer Day. In Greece organizations try to focus on the ways to creatively inform and encourage youth through art contests, essay about voluntarism, etc. In Poland and Luxembourg loans are granted in formal education under the condition of a documented history of at least three-year experience in volunteering.

The experience in volunteering, in Italy and Malta, are recognized as credits in basic university courses. Polish diplomas include information on participation in volunteer projects. In Ireland, some companies offer employees additional incentives to do volunteer activity. And in Romania, when selecting an employee for a vacancy, preference will be given to the applicant with an experience in volunteering in the required field. Also interesting is the experience of Lithuania,

14 О. Труворова, Эстонию взяли итурмом [Estonia had stormed], МК Эстония, http://rus. delfi.ee/press/mk_estonia/estoniyu-vzyali-shturmom?id=23300145 (accessed 14.03.15). 
where a project was implemented, in which people are offered a variety of activities to promote volunteering. Also in this country there are organized interactive programs and exhibitions of achievements in this area.

One of the main methods of encouraging young people to volunteer is to support Youth pass, which in turn is the European instrument for recognition of nonformal and informal learning in youth work. It is supported by Cyprus, Finland, Belgium, Bulgaria, Luxembourg, Malta, Slovenia, and Romania.

Also the issuance of a certificate of participation in volunteer projects is one of the methods of voluntary encouragement. But in different EU countries instruments differs. For example, in Italy and Cyprus including the existence of such a certificate in a resume has practically no effect. In France and Romania recognition of documents depends on the personal wishes of the employer. In Estonia, Sweden, Belgium, and Luxembourg these documents are recognized and appreciated.

\section{Financing}

The vast majority of voluntary organizations operate through membership fees. For example the main funding sources in Finland are: membership fees, donations, income from services rendered, selling products, advertising revenue (e.g. magazine NGO), contracts with private companies, grants from local and national authorities, EU funds, income from capital (such as rental income, etc.), and so on. In general, public subsidies account for $28 \%$ of the funding of voluntary organizations; EU funds and other ministries - 19\%, private sources (membership fees, donations, and fundraising) $-35 \%{ }^{15}$.

\section{Problems}

However, despite all the measures aimed at increasing the number of young volunteers, there are plenty of obstacles. In Croatia, for example, persons under 15 years of age may participate in volunteering only with the written consent of a parent or a legal guardian. In general, the lack of willingness to engage in volunteering was caused by: incompleteness and fragmentation of knowledge, lack of time, low work prestige, likely costs, absence of legislation and, accordingly, warranties, etc.

\footnotetext{
15 S. Myllyniemi, Information Sheet "Volunteering of Young People", Finland 2011.
} 


\section{Volunteering Ukrainian Youth}

In Ukraine, volunteer activity significantly intensified with the start of the antiterrorist operation in the east. However, volunteerism appeared in the early 1990s in Ukraine as it became an independent state. The first project where they worked on a voluntary charge were "hotlines". Volunteering does not impose any religious, gender, political or geographical restrictions. Historically, in Ukraine, the largest social group that performs volunteer work were high school students, university students, and other young people. The availability of more free time and a higher level of awareness, especially through the work of educational institutions can be seen as the main reasons for this.

Until 2011 the regulatory framework in this area was represented by the laws of Ukraine on social work with children and youth ${ }^{16}$ and Social Services ${ }^{17}$. Certain provisions of these documents identify social benefits and the need for volunteer work. In October 2011, the Law of Ukraine "On volunteering"18 entered into force.

There are some points that prevent the spread of volunteering in this document. In particular, participation in volunteering is available for a person less than 18 years old and with the written consent of parents for a person less than 16 years old. It means that involvement of children in promoting healthy lifestyles or assistance to disabled peers is illegal. Mandatory Social Security Volunteers and the inability of informal activity in this area can also lead to the loss of potential employees. Another obstacle is the need to obtain the legal status of "volunteer organization", because the overwhelming number of voluntary associations occur spontaneously and participate in actions that are ad hoc.

The question of whether to pay or not to pay wages to volunteers or reimburse their expenses is directly solved within voluntary organizations. The Law of Ukraine on volunteering states that civil servants' costs of performing volunteer work carried out is returned within the limits of reimbursement of travel expenses. In most cases, external sources are involved in volunteering funding. First of all, these are donations of businesses and individuals, grants and bank loans, and so on.

16 Закон України "Про сочіальну роботу з дітьми та молоддю" [Law of Ukraine "On Social Work with Children and Young People”], Відомості Верховної Ради України 2001, nо. 42, p. 213.

17 Закон України “Про сочіальні послуги” [Law of Ukraine „On Social Services”], Відомості Верховної Ради України 2003, по. 45, р. 358.

18 Закон України “Про волонтерську діяльність” [Law of Ukraine „On Volunteering”], BiАoмості Верховної РаАи України 2011, nо. 42, р. 435. 
Despite all the obstacles that arise in this area, there is large number of volunteer organizations operating in Ukraine. These are the documents of the Ministry of Social Policy, including Single Register of Volunteer Organizations ${ }^{19}$. During 2014 and the first quarter of 2015, 117 entities were given the status of volunteer organizations. Judging from the titles, the activities of these organizations are quite diverse: environmental conservation, rural development, dissemination of information on human rights, assistance to victims of the Chernobyl disaster, promoting economic development, helping the sick, supporting troops in eastern Ukraine, and so on.

According to the WORLD GIVING INDEX (world charity ranking), the rating of Ukraine gradually increased (Table. 1).

Table 1. The Rating of Ukraine

\begin{tabular}{|l|l|l|}
\hline Year & Place & Number of countries \\
\hline 2010 & 150 & 153 \\
\hline 2011 & 105 & 153 \\
\hline 2012 & 111 & 145 \\
\hline 2013 & 112 & 135 \\
\hline 2014 & 103 & 135 \\
\hline
\end{tabular}

Constructed on the basis of WORLD GIVING INDEX 2010-2014 20, 21, 22, 23, 24 .

Analyzing the data presented in the table, we can draw some conclusions. The most active volunteerism in Ukraine was in 2011. Most likely this is due to the proclamation of 2011 as the European Year of Volunteering and the preparation for the UEFA European Championship in 2012. In 2012, despite the reduction

19 Єдиний реєстр волонтерських організацій [Single Register of Volunteer Organizations], Офіційний веб-сайт Міністерства соціальної політики України, http://www.mlsp.gov.ua/ labour/control/uk/publish/category\%3Bjsessionid=5E38B213A546D7B45CBD2EE7B2AB5066. app2?cat_id=160017 (accessed 14.03.15).

20 World Giving Index 2010. A Global View of Giving Trends, https://www.cafonline.org/pdf/ WorldGivingIndex 28092010Print.pdf (accessed 14.03.15).

21 World Giving Index 2011. A Global View of Giving Trends, https://www.cafonline.org/pdf/ World_Giving_Index_2011_191211.pdf (accessed 14.03.15).

22 World Giving Index 2012. A Global View of Giving Trends. December 2012, https://www. cafonline.org/PDF/World GivingIndex2012WEB.pdf (accessed 14.03.15).

23 World Giving Index 2013. A Global View of Giving Trends. December 2013, https://www. cafonline.org/PDF/World GivingIndex2013_1374AWEB.pdf (accessed 14.03.15).

24 World Giving Index 2014. A Global View of Giving Trends. November 2014, https://www. cafonline.org/PDF/CAF_WGI2014_Report_1555AWEBFinal.pdf (accessed 14.03.15). 
of the countries studied, the rating dropped significantly. Starting from 2014, the situation is gradually improving.

Ukraine, like many volunteer organizations in the world, makes great efforts to popularize volunteering and involvement of many people, particularly young people. For this purpose a huge number of events that are extremely diverse in nature are implemented: pop stars' and bands' speeches, themed bike rides, workshops crafts, sports, etc. A variety of projects are being developed and implemented. In order to promote motivation for voluntary service Ukrainian community center "Volunteer" established a school for volunteers. In this school everybody has the opportunity to master the essential knowledge and skills needed to perform volunteer work.

As it was mentioned, in order to increase the efficiency of implementing changes in this area, it is necessary to distinguish problem areas. The basic tool of its detection is monitoring. In Ukraine, volunteering at the national level is not done. Observation and evaluation of volunteering is conducted by the voluntary organizations across their own association.

\section{Conclusions}

In the European Union issues involving young people in volunteering are a high priority, because it benefits both the society in general and youth in particular. In order to achieve this goal Commonwealth countries have done a lot, from supranational regulatory framework to the specific local examples. But there are some problems for which, above all, it is necessary to establish a monitoring system at the national level. In Ukraine, volunteer activity significantly intensified with the start of the antiterrorist operation in the east. However, many volunteer organizations direct their activities in other sectors. Despite the obstacles, including the legislation and limited resources, the number of volunteer organizations increases. It is gradually increasing the rating of Ukraine in volunteer activities in relation to the rest of the international community. As in the EU, Ukraine needs to improve monitoring issues; it is only when it detects obstacles that it can find effective solutions. 